\title{
Did Australia's Fiscal Stimulus Counter Recession?: Evidence from the National Accounts
}

\author{
ANTHONY J. MAKIN ${ }^{1}$
}

\section{Abstract}

A close scrutiny of the pattern of aggregate expenditure recorded in the Australian national accounts reveals it was the behaviour of exports and imports, and not increased fiscal activity, that was primarily responsible for offsetting the fall in private investment due to the Global Financial Crisis. The examination of a broad set of national income and employment indicators suggests that the Australian economy most likely did not avoid a recession, even though it was a relatively mild one by past standards.

\section{Introduction}

To counter a recession that was widely predicted in the wake of the Global Financial Crisis (GFC), the Australian government implemented one of the largest fiscal responses in the world in 2008-09 (IMF 2009). This was despite the relative soundness of Australia's banks compared to those in far worse-affected North Atlantic economies, whose systemic banking problems precipitated the GFC.

Extra Federal spending was unveiled in a series of fiscal packages, beginning with the Economic Security Strategy in October 2008 (\$10.4 billion), the Nation Building package in December 2008 ( $\$ 4.7$ billion), the Nation Building and Jobs Plan in February 2009 ( $\$ 41.5$ billion) and further Nation Building infrastructure measures in the May 2009 Federal budget (Uren and Taylor 2010: 249-50).

1 Griffith Business School, Griffith University; t.makin@griffith.edu.au. The author thanks the Editor, William Coleman, and an anonymous referee for constructive comments. 
This fiscal stimulus involved a mix of income transfers to select groups, as well as new public expenditure on different forms of infrastructure, including school construction and refurbishment, social housing, home insulation and limited tax breaks for business. It aimed to stimulate aggregate demand through increased consumption and investment expenditure and has been credited with saving Australia from recession (Australian Treasury Budget Papers 2010).

More specifically, the claim that Australia avoided recession, based on a definition of recession as two consecutive quarters of declining real GDP, turns on the positive real GDP result recorded for the March 2009 quarter, after the originally published negative December 2008 outcome. On the grounds that fiscal stimulus saved Australia from recession, former Prime Minister Kevin Rudd reportedly suggested that the day the Australian Bureau of Statistics released the March quarter national accounts data, 3 June 2009, was the best day of his prime ministership (Uren and Taylor 2010: 205).

However, two key data-related questions about the performance of the Australian economy at that critical time still need to be addressed. The first is how effective fiscal stimulus was in avoiding a recession, defined as two quarters of negative growth. The second is whether the economy did actually avoid a recession in light of a broader set of national accounts and labour-market indicators.

This paper aims to address these questions by thoroughly examining the latest quarterly national accounts data published by the Australian Bureau of Statistics (ABS Catalogue 5306.0) for the interval from September 2008 to December 2009. Close scrutiny of the pattern of aggregate expenditure recorded in the national accounts, especially for the December 2008 and March 2009 quarters, reveals it was the behaviour of exports and imports, not increased fiscal activity, that was primarily responsible for offsetting the fall in private investment due to the GFC. However, the size and sign of the statistical discrepancy in the national accounts implies that the expenditure-based GDP estimates need to be interpreted cautiously.

Next, the paper contends that when assessed with reference to a broader set of national income and employment indicators, as is standard practice for dating recessions in the United States, the Australian economy most likely did not avoid a recession, even though it was a relatively mild one by past standards. 


\section{What National Accounts Data Tell Us About the Fiscal Stimulus}

Historically, swings in private investment, rather than in household consumption, have been the main driver of Australia's business cycle because consumption tends to be relatively stable in the face of temporary income shocks, consistent with so-called consumption smoothing behaviour. Fiscal stimulus measures aimed to offset a fall in private investment, which initially manifested predominantly as a rundown in inventories, by boosting domestic consumption and public investment expenditure.

The GFC and its immediate aftermath most affected the Australian economy in the September 2008, December 2008, March 2009 and June 2009 quarters. Over this time many other economies experienced sharp falls in GDP and were party to what the International Monetary Fund termed 'The Great Recession' in 2008-09. What do the data for Australian GDP record?

The ABS publishes GDP series on an 'original', 'seasonally adjusted', and 'trend' basis, and recommends the 'trend' series for policy analysis. Although there are many interpretations of the term 'trend', in the context of national accounts analysis the Australian Statistician uses this term to refer to the underlying path traced by the cyclical behaviour of the series. Thus the 'trend' is not an average that smooths out cyclical disturbances. Technical discussion of the statistical techniques used to derive the national accounts trend series, which can differ significantly quarter by quarter from original and seasonally adjusted data, are discussed at length in ABS (2003).

Consistent with the recommendation in that publication and the emphasis the ABS itself gives in its commentaries in national accounts releases, GDP trend data are used in what follows, except when discussing the contribution of expenditure types to quarterly changes in GDP, which is published only on a seasonally adjusted basis. For the time interval under scrutiny, it is noteworthy that the seasonally adjusted national accounts data, when not separately included in data tables to follow, do tend to show that the economy performed worse than indicated by the trend series. Table 1 includes the main GDP series for Australia over this time, with deteriorations in quarterly changes recorded in boldface. 
Agenda, Volume 17, Number 2, 2010

Table 1: Conventional Measures of Gross Domestic Product (percentage growth per quarter, trend basis)

\begin{tabular}{lrrrrrr}
\hline & $\begin{array}{r}\text { Real GDP- } \\
\text { Expenditure }\end{array}$ & $\begin{array}{r}\text { Real GDP- } \\
\text { Income }\end{array}$ & $\begin{array}{r}\text { Real GDP } \\
\text {-Production }\end{array}$ & $\begin{array}{r}\text { Real GDP- } \\
\text { Average }\end{array}$ & $\begin{array}{r}\text { Real GDP } \\
\text { per capita }\end{array}$ & $\begin{array}{r}\text { Nominal } \\
\text { GDP }\end{array}$ \\
Jun-2008 & 0.3 & 0.3 & 0.7 & 0.4 & 0.1 & 2.8 \\
Sep-2008 & 0.1 & -0.2 & 0.2 & 0.0 & -0.5 & 2.1 \\
Dec-2008 & 0.4 & -0.2 & -0.2 & 0.0 & -0.5 & 0.6 \\
Mar-2009 & 0.7 & 0.2 & -0.2 & 0.2 & -0.3 & -0.8 \\
Jun-2009 & 0.9 & 0.5 & 0.1 & 0.5 & 0.0 & -0.7 \\
Sep-2009 & 0.9 & 0.5 & 0.6 & 0.6 & 0.2 & 0.7 \\
Dec-2009 & 0.8 & 0.6 & 0.9 & 0.8 & 0.3 & 2.2 \\
\hline
\end{tabular}

Source: Australian Bureau of Statistics, Australian National Accounts, Catalogue 5306; available at www. abs.gov.au/Ausstats

The first three columns record GDP by the national expenditure GDP(E), national income GDP(I) and national production GDP(P) methods. In principle, of course, the value of the conventional GDP measure for any quarter should have the same value, regardless of whether it is based on expenditure, income, or production. Yet, in practice, these three different approaches to GDP typically yield quite different results as a result of measurement problems.

For this reason, they are averaged by the ABS, with the size of the statistical discrepancy for any single measure reflecting the difference between that measure and the average of all three. The quarterly change in the average GDP measure, GDP(A), in trend terms was positive, at 0.2 per cent in real (or volume) terms for the March 2009 quarter following zero growth in the December quarter, implying that a recession, as defined above, was technically avoided.

Of notable interest, however, is the behaviour of nominal GDP, which fell in the March 2009 and June 2009 quarters, implying a contraction in national income. The reason the average volume measure of GDP remained positive in the March quarter, while the current price value measure shrank, is that there was a sharp fall in the implicit price deflator (or overall price level), due in no small part to heavy retail discounting of goods for sale at this time. Meanwhile, real GDP per head, the single most important indicator of recession, fell successively over three quarters by a total of 1.3 per cent.

The real GDP(E) measure in Table 1 is the only conventional GDP series that did not record at least two consecutive negative outcomes. Average real GDP was not negative for two successive quarters because the GDP(E) measures were sufficiently positive to make GDP(A) positive. Hence, the claim that fiscal 
stimulus enabled Australia to avoid recession according to the media definition of recession, in the end depends on the nature and robustness of the real GDP(E) measure for the March 2009 quarter.

Advocates of fiscal stimulus would argue that a high GDP(E) outcome should be unsurprising since the explicit purpose of fiscal stimulus is to expand aggregate expenditure. The issue which then arises, however, is whether Federal fiscal stimulus measures were mainly responsible for achieving the high and discrepant GDP(E) result for the March 2009 quarter. Put differently, how successfully did fiscal activity achieve this objective with reference to the contributions of consumption and investment to expenditure between the June 2008 and December 2009 quarters?

To answer this question, it is necessary to scrutinise the GDP expenditure data during the GFC impact period in more detail, paying particular attention to the main expenditure components - private consumption, public consumption, private investment, public investment, exports and imports. In the national accounts, quarter- to-quarter impacts of these expenditure items in seasonally adjusted terms are termed 'contributions to growth', the magnitude of which over the relevant time span are depicted in Figure 1.

\section{Figure 1: Contribution to Change in GDP by Expenditure}

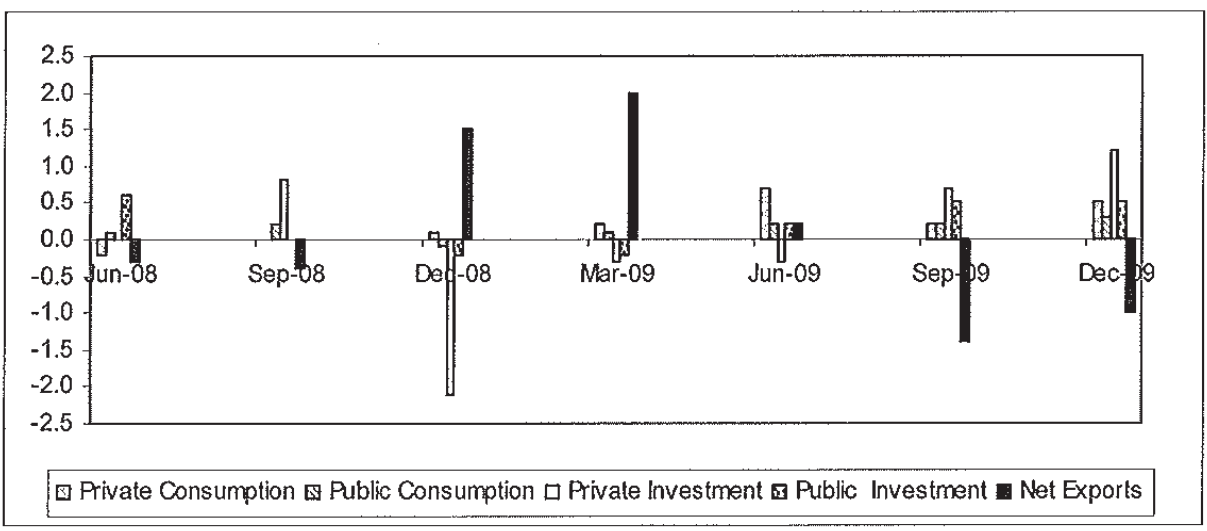

Source: Australian Bureau of Statistics, Australian National Accounts, Catalogue 5306; available at www. abs.gov.au/Ausstats

With reference to the December 2008 and March 2009 quarters, what is apparent is that by far the most significant contributor to GDP(E) in those quarters was net exports, which detracted from real expenditure growth in quarters before and after the GFC struck. The strong net export result can be explained by a sustained real exchange-rate depreciation of over 25 per cent in trade-weighted terms during the December 2008 and March 2009 quarters, which made exports 
substantially cheaper for foreign buyers and imports more expensive for domestic buyers. There was also sustained demand for commodities from key Asian trading partners, including China, over this time.

A sizeable component of the fiscal stimulus packages implemented during the GFC period focused on cash bonuses to individuals, which were intended to raise household income and hence private consumption indirectly. Private consumption did increase minimally in the March 2009 quarter, to 0.2 per cent, after contributing 0.1 per cent in the December 2008 quarter. However, given the dramatic lowering of official interest rates and substantial discounting of retail merchandise over this period, the size of the impact of the Federal cash bonuses, a major part of the fiscal-stimulus strategy, is open to question.

At most, cash bonuses are only likely to be responsible for a fraction of the small private consumption turnaround. This pales in comparison with the net exports contribution, and is less than the private investment improvement in the March quarter. In turn, this private investment improvement was due to a significant reversal of inventory rundown, in large part due to increases in farm inventory arising from a breaking of the drought.

Table 2: Contributions to GDP Growth (percentage points per quarter, seasonally adjusted)

\begin{tabular}{|c|c|c|c|c|c|c|}
\hline & $\begin{array}{r}\text { Federal } \\
\text { Government } \\
\text { Consumption }\end{array}$ & $\begin{array}{r}\text { State and } \\
\text { Local Govt } \\
\text { Consumption }\end{array}$ & $\begin{array}{r}\text { Federal } \\
\text { Government } \\
\text { Investment }\end{array}$ & $\begin{array}{l}\text { State and } \\
\text { Local Govt } \\
\text { Investment }\end{array}$ & $\begin{array}{r}\text { Statistical } \\
\text { Discrepancy }\end{array}$ & $\begin{array}{l}\text { Real } \\
\text { GDP }\end{array}$ \\
\hline $\begin{array}{l}\text { Jun- } \\
2008\end{array}$ & 0.0 & 0.1 & 0.3 & 0.3 & -0.1 & 0.2 \\
\hline $\begin{array}{l}\text { Sep- } \\
2008\end{array}$ & 0.1 & 0.1 & -0.2 & -0.1 & -0.1 & 0.4 \\
\hline $\begin{array}{l}\text { Dec- } \\
2008\end{array}$ & -0.1 & 0.1 & -0.2 & -0.1 & 0.0 & -0.7 \\
\hline $\begin{array}{l}\text { Mar- } \\
2009\end{array}$ & 0.0 & 0.1 & -0.1 & 0.0 & -0.9 & 0.7 \\
\hline $\begin{array}{l}\text { Jun- } \\
2009\end{array}$ & 0.0 & 0.1 & 0.0 & 0.1 & -0.3 & 0.5 \\
\hline $\begin{array}{l}\text { Sep- } \\
2009\end{array}$ & 0.2 & 0.1 & 0.0 & 0.2 & -0.1 & 0.3 \\
\hline $\begin{array}{l}\text { Dec- } \\
2009\end{array}$ & 0.3 & 0.1 & 0.2 & 0.3 & 0.0 & 1.0 \\
\hline
\end{tabular}

Source: Australian Bureau of Statistics, Australian National Accounts, Catalogue 5306; available at www. abs.gov.au/Ausstats

Of course, fiscal stimulus also involved direct government spending. Table 2 provides a more detailed breakdown of the respective contributions, on a seasonally adjusted basis, by level of government to consumption and 
investment spending over the period affected by the GFC and its aftermath. The recorded contribution from direct Federal government consumption to a change in GDP(E) in the December 2008 quarter was actually negative $(-0.1$ per cent), followed by nil contribution in the March quarter. These were offset by negligible positive contributions from State and Local consumption spending.

Similarly, Federal public investment actually contributed negatively to total expenditure over the critical December 2008 and March 2009 quarters, being -0.2 and -0.1 respectively, as did public investment by State and Local governments. As a result of administrative delays in implementing infrastructure spending, total public spending did increase by the end of 2009, but only after the worst of the GFC had passed, and then arguably crowded out private investment spending at the time.

These delays accord with numerous empirical studies of discretionary fiscal expansion in advanced economies, which tends to impact well after economic downturns begin. For instance, in a study of G7 economies for the period 1980 to 2007, IMF economists Leigh and Stehn (2009) conclude that fiscal stimulus in the form of capital spending arrived on average around a year after the onset of a downturn. This is consistent with earlier studies by Auerbach (2003), Galí and Perotti (2003) and Lane showing that in practice fiscal stimulus in the past has been either weakly countercyclical or procyclical in OECD economies.

To summarise, the main expenditure items from the national accounts contributing to GDP(E) for the March 2009 quarter can be expressed as:

$$
\begin{gathered}
\text { Private Consumption }(0.2 \%)+\text { Public Consumption }(0.1 \%) \\
+ \text { Private Investment }(-0.5 \%)
\end{gathered}
$$

+ Public Investment $(-0.2 \%)+$ Net Exports (2.0\%) + Statistical Discrepancy (-0.9\%)

$$
=G D P(0.7 \%)
$$

Thus, the net positive contributions of private and public consumption totalling 0.3 per cent were insufficient to offset the negative contributions from private and public investment (inclusive of inventory changes) of 0.7 per cent, and were minor in relation to the contribution from net exports of 2.0 per cent.

It is also important to note that, at -0.9 per cent, the statistical discrepancy between the GDP(E) measure and the GDP(A) measure in the March 2009 quarter was very large by historical standards. This suggests an overstatement of measured expenditure relative to measured production. Given the magnitude of this discrepancy, it raises serious doubts about the robustness of the GDP(E) series for the March quarter. Yet, this particular GDP series is central to achieving the positive real GDP(A) result that justifies the claim that Australia avoided recession at that time. 


\section{Did Australia Avoid Recession in 2008-09?}

The claim that Australia avoided a recession rests on the definition of recession as two consecutive quarters of falling GDP. This definition is popular with media commentators and market economists and is tacitly approved by the Australian Treasury and the Reserve Bank of Australia. However, it lacks support from academic economists and policymakers abroad. Disapproval of this narrow and somewhat arbitrary interpretation of recession is expressed in numerous mainstream macroeconomics texts, including one co-authored by Ben Bernanke, Chairman of the United States Federal Reserve (Abel, Bernanke and Croushore 2007).

Relying on just one indicator of macroeconomic activity, such as real GDP, is inappropriate because economy-wide data estimation is always subject to a margin of error, especially in the face of a major shock such as the GFC, as evidenced by large statistical discrepancies in the national accounts. As shown above in Table 1, two successive quarters of negative growth were recorded in nominal GDP, the real production and income-based measures of GDP, and real GDP per head. The real GDP(E) measure was the only series that did not fall over two successive quarters.

For decades in the United States a panel of independent economists under the auspices of the National Bureau of Economic Research has declared and dated recessions with reference to a battery of economic indicators, not just conventional real GDP series. Using a broader set of macroeconomic data series than the standard real GDP(A) measure is warranted in Australia as well, and a range of national income measures with subtle differences in meaning is available for this purpose.

Alternative national income series for Australia gleaned from the most recent set of national accounts are included in Table 3, all of which reveal at least two successive negative quarterly outcomes. Though routinely ignored in economic commentary, the real gross and net domestic and national income series are especially important measures of Australia's international macroeconomic performance because they reflect the impact of the terms of trade (or ratio of prices received for exports to prices paid for imports) on the economy. 
Table 3: Other National Income Measures (percentage growth per quarter, trend basis)

\begin{tabular}{lrrrrr}
\hline & $\begin{array}{r}\text { Real Net } \\
\text { Domestic } \\
\text { Product }\end{array}$ & $\begin{array}{r}\text { Real Gross } \\
\text { Domestic } \\
\text { Income }\end{array}$ & $\begin{array}{r}\text { Real Gross } \\
\text { National } \\
\text { Income }\end{array}$ & $\begin{array}{r}\text { Real Net National } \\
\text { Disposable } \\
\text { Income }\end{array}$ & $\begin{array}{r}\text { Real Net National } \\
\text { Disposable Income } \\
\text { per Capita }\end{array}$ \\
Jun-2008 & 0.3 & 2.2 & 2.5 & 2.7 & 2.2 \\
Sep-2008 & -0.3 & 1.2 & 1.6 & 1.5 & 1.0 \\
Dec-2008 & -0.4 & -0.3 & -0.2 & -0.5 & -1.1 \\
Mar-2009 & -0.1 & -1.2 & -1.2 & -1.8 & -2.3 \\
Jun-2009 & 0.4 & -0.5 & -0.6 & -1.0 & -1.5 \\
Sep-2009 & 0.5 & 0.3 & 0.3 & 0.1 & -0.3 \\
Dec-2009 & 0.4 & 0.7 & 0.7 & 0.6 & 0.2 \\
\hline
\end{tabular}

Source: Australian Bureau of Statistics, Australian National Accounts, Catalogue 5306; available at www. abs.gov.au/Ausstats

Derived by adjusting the volume measure of GDP for changes in the international purchasing power of national income which, in Australia's case, occurs due to fluctuating export commodity prices, these series are broader measures of national economic wellbeing than the standard real GDP measure used in the media definition of recession. Specifically, real gross domestic income, consistent with the definition in the ABS Catalogue 5206.0 glossary, is derived as:

$G D P(A)$ in constant prices - Exports in constant prices + Exports at current prices deflated by the Implicit Price Deflator for Imports.

In other words, real GDP is adjusted by revaluing exports in terms of the implicit price deflator.

The differences between the measures Real Gross Domestic Income and Real Gross National Income and Real Net National Disposable Income in Table 3 reflect adjustments for capital consumption, and income remittances and transfers abroad. It is noteworthy that in 2008-09, all of these measures recorded their most significant falls since the recession of the early 1990s.

It is also appropriate to supplement the set of national income series in Tables 1 and 3 with aggregate labour-market data. Table 4 includes a selection of labourmarket indicators which reveal that employment conditions unambiguously worsened over the interval under scrutiny. Consistent with historical experience, these indicators tended to lag the deteriorations in the GDP(P) and GDP(I) series over the GFC interval.

Most notably, hours worked fell by 1.3 per cent in the March quarter after a 1.1 per cent fall in the December quarter and by 3.2 per cent between the September 2008 and June 2009 quarters, whereas unemployment rose by 1.1 per cent and 1.5 per cent over these respective periods. 
Table 4: Labour-market Indicators (percentage growth per quarter, seasonally adjusted)

\begin{tabular}{lrrrrr}
\hline & & & & $\begin{array}{r}\text { Nominal } \\
\text { Non-farm }\end{array}$ & \\
& $\begin{array}{r}\text { Hours } \\
\text { Worked }\end{array}$ & $\begin{array}{r}\text { Real GDP } \\
\text { Market sector }\end{array}$ & $\begin{array}{r}\text { Hours Worked } \\
\text { Market Sector }\end{array}$ & $\begin{array}{r}\text { Compensation } \\
\text { of Employees }\end{array}$ & $\begin{array}{r}\text { Unemployment } \\
\text { Rate }\end{array}$ \\
Jun-2008 & 0.9 & $\%$ & $\%$ & $\%$ & $\%$ \\
Sep-2008 & 0.3 & 0.7 & 0.3 & 2.6 & 4.2 \\
Dec-2008 & -0.4 & 0.0 & -1.0 & 1.8 & 4.3 \\
Mar-2009 & -0.7 & -0.7 & -1.3 & 1.1 & 4.6 \\
Jun-2009 & -0.4 & -1.1 & -1.1 & -0.2 & 5.7 \\
Sep-2009 & 0.1 & 0.4 & -0.2 & -0.5 & 5.8 \\
Dec-2009 & 0.6 & 0.5 & -1.2 & 0.2 & 5.7 \\
\hline
\end{tabular}

Source: Australian Bureau of Statistics, Australian National Accounts, Catalogue 5306; available at www. abs.gov.au/Ausstats. Reserve Bank of Australia; available at www.rba.gov.au/statistics

Combining the above national income measures in Tables 1 and 3 with the labour-market indicators in Table 4 provides a more comprehensive picture of Australian macroeconomic conditions as a result of the GFC than that conveyed by the media definition of recession based on only one national accounts series. When worsening quarterly outcomes for a larger set of indicators are aggregated, a pattern emerges of an economy that failed to improve in the critical March 2009 quarter, not one that avoided recession, arbitrarily defined. Overall, however, the array of macroeconomic indicators suggests that the downturn was relatively mild by historical standards.

It should also be noted that these data, drawn mainly from the national accounts, are by no means an exhaustive set for assessing the business cycle. Including additional indicators (some leading, some co-incident, some lagging) for national wealth, building approvals, firms' profitability, retail sales and other activity measures would be expected to provide further evidence of a recession at this time.

When dating the duration of recessions in the United States, how long national income significantly deviates from trend growth, known as the growth-cycle measure of the business cycle, is also taken into account; see Hall and Taylor (1993). The growth-cycle approach defines recessionary intervals as those when activity persists below long-term trend growth, whereas the above national accounts series simply reflect levels of economic activity. 


\section{Conclusion}

The case for fiscal stimulus was based on the presumption that it would work along lines first proposed by Keynes (1936); that macroeconomic activity was demand-determined in the short run and that public spending could increase domestic aggregate demand. What this interpretation ignores, however, is the role that the nominal exchange rate can play in insulating the real domestic economy from the worst effects of a foreign financial shock via its stimulatory impact on net exports, as modelled more formally in Makin (2010).

Using raw data from Australia's national accounts, this paper establishes that net foreign demand (as reflected in quarterly changes in exports and imports), not federal fiscal stimulus, was primarily responsible for countering the GFCinduced economic slowdown over the December 2008 and March 2009 quarters. Indeed, the Federal government's direct contribution to the change in domestic consumption and investment was minimal at that time, with its major impact arriving several quarters after it was deemed necessary.

Considered in isolation, the somewhat arbitrary media measure of two successive quarters of declining real GDP provides a misleading picture of macroeconomic conditions. The statistical discrepancy, especially the discrepancy associated with the GDP expenditure measure, was very large by historical standards during the GFC period, suggesting a broader set of national income measures from the national accounts should be used.

Taken together, numerous national income measures and employment indicators suggest Australia, through no economic fault of its own, most likely experienced a mild recession by historical and international standards in 2008-09. Ideally, whether and when recessions do occur in Australia should depend on the comprehensive assessment and judgement of an independent panel of academic economists in the spirit of the approach practised in the United States.

\section{References}

Abel, A., Bernanke, B. and Croushore, D. (2007) Macroeconomics (6th edition) Addison Wesley, New York.

Auerbach, A. 2003, 'Fiscal Policy: Past and Present', Brookings Papers on Economic Activity: 75-138.

Australian Bureau of Statistics 2000, Australian National Accounts: Concepts, Sources and Methods, Catalogue 5216, Australian Bureau of Statistics, Canberra. 
Australian Bureau of Statistics 2010, Australian National Accounts: National Income, Product and Expenditure, Catalogue 5306, Australian Bureau of Statistics, Canberra.

Australian Bureau of Statistics 2003, A Guide to Interpreting Time Series: Monitoring Trends, Catalogue 1349.0, Australian Bureau of Statistics, Canberra.

Australian Treasury 2010, Budget Papers 2010-2011, Australian Government Printing Service, Canberra.

Galí, Jordi and Perotti, Roberto 2003, "Fiscal Policy and Monetary Integration in Europe", Economic Policy 37: 533-72.

Hall, R. and Taylor, J. 1993 (4th edition), Macroeconomics, Norton, New York.

International Monetary Fund 2008, World Economic Outlook, September, IMF, Washington DC.

International Monetary Fund 2009, Global Economic Policies and Prospects, Group of Twenty Meeting, March, IMF, Washington DC.

Lane, P. 2003, "The Cyclical Behaviour of Fiscal Policy: Evidence from the OECD" Journal of Public Economics 87: 2661-75.

Leigh, D. and Stehn, J. 2009, “Fiscal and Monetary Policy During Downturns: Evidence from the G7", IMF Working Paper WP/09/50, International Monetary Fund, Washington DC.

Keynes, J. M. 1936, The General Theory of Employment, Interest and Money, Macmilllan, Houndsmills, U.K.

Makin, A. 2010, "How Should Macroeconomic Policy Respond to Foreign Financial Crises?” Economic Papers 29(2): 1-10.

Mankiw, G. 2010, Macroeconomics (7th edition), Worth, New York.

Reserve Bank of Australia 2010, Statistical Tables; available at http://www.rba. gov.au/statistics/index.html

Taylor, L. and Uren, D. 2010, Shitstorm, Melbourne University Press, Melbourne. 